\title{
Comparison of net pasture yield with continuous and rotational grazing at a high level of nitrogen fertilization
}

H. Schlepers and E. A. Lantinga (Department of Field Crops and Grassland Science, Agricultural University, Haarweg 333, 6709 RZ Wageningen, Netherlands)

Received 2 October 1985; accepted 16 December 1985

\begin{abstract}
A comparative trial with dairy cows revealed that there was no difference in net pasture yield between continuous and rotational grazing, when managed at a stocking rate between 3.0 and 3.4 cows ha- ${ }^{-1}$ and with a $\mathrm{N}$ fertilization of $440 \mathrm{~kg} \mathrm{ha}^{-1}$ $\mathrm{yr}^{-1}$. The net pasture yield was calculated from the animal production data and the yield of harvested silage grass. Under continuous grazing a mean sward height of about $10 \mathrm{~cm}$ was maintained. It is noted that the actual optimum mean sward height with continuous grazing is about $7 \mathrm{~cm}$. Under such management the net pasture yield is increased.

Key-words: continuous grazing, rotational grazing, net pasture yield.
\end{abstract}

Introduction. At present, rotational grazing, with grazing periods of 2 to 5 days, is the most common grazing system for dairy cows in the Netherlands. In some countries of north-western Europe, however, there has been a move to continuous grazing recently. This was due mainly to the results of comparative trials, carried out in the mid-1970s in the United Kingdom, Germany and Belgium, which showed a similar pasture output at high nitrogen fertilization levels and high stocking rates (Ernst et al., 1980). Continuous grazing has the advantage over rotational grazing that labour input can be considerably lower and that sward density is increased which may resist weed ingress and sward deterioration. Therefore, a comparative trial with continuous and rotational grazing at high nitrogen fertilization was set up with special attention to net pasture yield and sward quality.

Materials and methods. The experiment was carried out on a silty clay cloam during 1978-1980 in the new land of the Flevo Polders. The experimental area was 13.9 ha in 1978 and 1979 and 11.7 ha in 1980 , for each system. The $\mathrm{N}$ fertilization was on average $440 \mathrm{~kg} \mathrm{ha}^{-1} \mathrm{yr}^{-1}$. The stocking rate was the same each year in both grazing systems. Spring-calving cows were used at a stocking rate of 3.4 cows ha- ${ }^{-1}$ in 1978 and of 3.0 cows ha $\mathrm{a}^{-1}$ in 1979 and 1980 . In both systems the cows grazed day and night. Under rotational grazing the average length of a grazing period was 4 days. Under continuous grazing the aim was to maintain a mean sward height of about 10 $\mathrm{cm}$. The sward height was measured with a round tempex disc with a diameter of 50 $\mathrm{cm}$ and a weight of $150 \mathrm{~g}$. In both systems cleaning cuts were taken when necessary and the yield of cut grass was measured. Silage cuts were taken in the rotational grazing system from paddocks which were not required for grazing. In the continu- 
ous grazing system the paddock was partly enclosed for silage when the height of grass could not be maintained at about $10 \mathrm{~cm}$ by the cows. Concentrate supplementation was on an average $3 \mathrm{~kg} \mathrm{cow}^{-1} \mathrm{~d}^{-1}$ throughout the grazing season. During October 1978 it was necessary to feed additional maize silage $\left(3 \mathrm{~kg} \mathrm{DM} \mathrm{cow}^{-1} \mathrm{~d}^{-1}\right)$ to both systems due to a shortage of standing herbage.

Total milk production of both groups was collected in separate tanks and measured and analysed for fat by the dairy factory. The animals were weighed every month.

Results and discussion. The net pasture yield was calculated from the animal production data by using standards for nutrient requirements of grazing cows and the yield of silage cuts. Expressed in Dutch feed units (VEM) the daily energy requirement for grazing dairy cows is (van Es, 1978; C.V.B., 1979; Meijs, 1981):

$$
(4700+6(\mathrm{~W}-550)) \times 1.2+460 \mathrm{FCM}+3000 \mathrm{G}
$$

where $\mathrm{W}$ is liveweight $\left(\mathrm{kg} \mathrm{cow}^{-1}\right)$;

FCM is fat-corrected milk production $\left(\mathrm{kg} \mathrm{cow}^{-1} \mathrm{~d}^{-1}\right)$;

$\mathrm{G}$ is liveweight gain $\left(\mathrm{kg} \mathrm{cow}^{-1} \mathrm{~d}^{-1}\right)$.

In Eq. 1 it is assumed that the maintenance requirement for grazing cows is $20 \%$ higher than for stall-fed cows.

Eq. 1 was used to estimate the total energy requirement per ha over the grazing season, taking an average liveweight of the cows of $570 \mathrm{~kg}$. The net pasture yield is the energy requirement according to Eq. 1 plus the VEM yield of silage grass minus the energy consumption from supplements. For silage grass an average figure of $830 \mathrm{VEM} \mathrm{kg}^{-1} \mathrm{DM}$ was assumed. The results are summarized in Table 1.

It can be concluded that the net pasture yield was the same under the two grazing

Table 1 . Summary of the results. $\mathrm{R}=$ rotational grazing; $\mathrm{C}=$ continuous grazing.

\begin{tabular}{|c|c|c|c|c|c|c|c|c|}
\hline & \multicolumn{2}{|l|}{1978} & \multicolumn{2}{|l|}{1979} & \multicolumn{2}{|l|}{1980} & \multicolumn{2}{|c|}{ Average $1978-1980$} \\
\hline & $\mathrm{R}$ & $\mathrm{C}$ & $\mathrm{R}$ & $\mathrm{C}$ & $\mathrm{R}$ & $\mathrm{C}$ & $\mathbf{R}$ & $\mathrm{C}$ \\
\hline Cow grazing days $\left(h^{-1}\right)$ & 566 & 566 & 440 & 446 & 515 & 515 & 507 & 509 \\
\hline $\begin{array}{l}\text { Increase in liveweight } \\
\left(\mathrm{kg} \mathrm{ha}^{-1}\right)\end{array}$ & 136 & 104 & 216 & 212 & 91 & 61 & 148 & 126 \\
\hline $\begin{array}{l}\text { Milk production } \\
\left(\mathrm{kg} \mathrm{FCM} \mathrm{ha}^{-1}\right)\end{array}$ & 11965 & 11788 & 9743 & 9721 & 11327 & 11334 & 11012 & 10948 \\
\hline $\begin{array}{l}\text { Total yield of silage grass } \\
(\mathrm{kg} \mathrm{DM} \mathrm{ha-1)}\end{array}$ & 1696 & 2242 & 2452 & 2404 & 3375 & 3321 & 2508 & 2656 \\
\hline $\begin{array}{l}\text { Supplementary feed } \\
\text { (kVEM ha-1) } \\
\text { Net pasture yield }\end{array}$ & 1599 & 1599 & 1296 & 1322 & 1242 & 1243 & 1379 & 1388 \\
\hline $\begin{array}{l}\left(\mathrm{kVEM} \mathrm{ha}^{-1}\right) \\
\text { (relative) }\end{array}$ & $\begin{array}{c}8992 \\
(100.0)\end{array}$ & $\begin{array}{c}9267 \\
(103.1)\end{array}$ & $\begin{array}{l}8412 \\
(100.0)\end{array}$ & $\begin{array}{l}8359 \\
(99.4)\end{array}$ & $\begin{array}{l}10019 \\
(100.0)\end{array}$ & $\begin{array}{r}9887 \\
(98.7)\end{array}$ & $\begin{array}{c}9141 \\
(100.0)\end{array}$ & $\begin{array}{c}9171 \\
(100.3)\end{array}$ \\
\hline $\begin{array}{l}\text { Total yield of cleaning cuts } \\
\left(\mathrm{kg} \mathrm{DM} \mathrm{ha}^{-1}\right)\end{array}$ & 1222 & 119 & 489 & 160 & 278 & 191 & 663 & 157 \\
\hline
\end{tabular}


systems each year. The increase in liveweight was a little higher under rotational grazing, but this was compensated by a higher yield of silage grass from the area of the continuous grazing system.

It can be seen in Table 1 that the topping losses were greater with rotational grazing, especially in 1978 . This was because in some cases the grass was actually too long for grazing, which resulted in large grazing residues removed by a cleaning cut. At the end of the grazing season (mid-October) the herbage yield was on average $350 \mathrm{~kg} \mathrm{DM} \mathrm{ha} \mathrm{k}^{-1}$ greater in the continuously grazed area. This partly counter-balanced the greater topping losses under rotational grazing.

Between the experimental years there was some variation in pasture output. The low number of grazing days attained in 1979 was due to the severe winter of $1978 / 1979$. Many tillers died and the start of the grazing season was about two weeks later than in 1978 and 1980 . However, some compensation took place during late summer and autumn of that year, when the weather was favourable for grass growth and grazing. This may explain the relatively high increase in liveweight during 1979.

Under very wet conditions sward damage due to trampling was more serious under rotational than under continuous grazing. To avoid severe damage it was necessary to remove the cattle a few times from the paddocks of the rotational grazing system. This was not necessary with continuous grazing.

The overall sward quality, in terms of botanical composition and tiller density, was very similar under the two grazing systems at the end of the 3-year comparison. Tiller density in the areas of the continuously grazed pasture which were closely grazed was higher than in large areas with uneaten grass surrounding dung patches. In all of the three experimental years topping was needed in early summer to remove this long grass. Other (Ernst et al., 1980) and more recent research (Lantinga, 1985) has shown, however, that a mean sward height of about $10 \mathrm{~cm}$ with continuous grazing, as was the case in the present study, is too high; the optimum is actually about $7 \mathrm{~cm}$. Then the total area of rejected grass is relatively small and the mean tiller density in the pasture can be twice as high as under a common rotational grazing system, whereas individual animal intake is not depressed. Moreover, there are indications that under such management the net pasture yield with continuous grazing is higher than can be achieved with rotational grazing provided that the intake per cow from the pasture is not or hardly restricted due to the amount of herbage on offer.

\section{References}

C.V.B., 1979. Veevoedertabel. Centraal Veevoederbureau in Nederland, Lelystad.

Ernst, P., Y. L. P. Le Du and L. Carlier, 1980. Animal and sward production under rotational and continuous grazing management - a critical appraisal. In: W. H. Prins and G. H. Arnold (Eds.), The role of nitrogen in intensive grassland production, pp. 119-126. Proceedings of an International Symposium of the European Grassland Federation. Pudoc, Wageningen.

Es, A. J. H. van, 1978. Feed evaluation for ruminants. I. The system in use from May 1977 onwards in The Netherlands, Livestock Production Science 5: 331-345. 


\section{H. SCHLEPERS AND E. A. LANTINGA}

Lantinga, E. A., 1985. Productivity of grasslands under continuous and rotational grazing. Doctoral Thesis, Agricultural University, Wageningen, $111 \mathrm{pp}$.

Meijs, J. A. C., 1981. Herbage intake by grazing dairy cows. Agricultural Research Reports 909, Pudoc, Wageningen, $264 \mathrm{pp}$.

This synopsis is based on a report entitled 'Vergelijking van de onderzoeksresultaten van drie jaar omweiden-standweiden (1978-1980) op de Ir. A. P. Minderhoudhoeve te Swifterbant'. Mededeling No 66, Vakgroep Landbouwplantenteelt en Graslandkunde, Landbouwhogeschool, Wageningen, 1982. 24 pp., 12 tables, 8 refs., 9 appendices. Dutch.

Available as paper copy (order R045P, $f 20$ including postage) or microfiche (order R045M, $f$ 12,50 including postage) at: NARD, clo Pudoc, P.O. Box 4, 6700 AA Wageningen, Netherlands (telex 45015 blhwg $\mathrm{nl}$ ). 